\title{
Verden er, som den er
}

\section{Merete Pryds Helle}

En forfatter skal altid vælge, og altid vælge i begyndelsen af teksten; skal denne novelle eller roman være skrevet i første person, i tredie person, eller i en helt anden form? Hvis forfatteren vælger første person ental, er historien allerede farvet - det er et jeg, der taler gennem teksten.

Det er ikke alle historier, der er fortalt i første person, der handler om det jeg, der taler. Historien kan sagtens handle om mord, om rosenhaven i august, om kedsomhed. Men der er en mulighed for, at historien handler om den, der fortæller den.

I „Time Out" får fortællerforholdet en drejning til, fordi historien, fortalt i jeg-person, ikke bare handler om fortælleren, den handler om, hvad et jeg overhovedet er. Eller ikke er.

Det er en bevidsthed, der siger jeg om sig selv. Der er en masse himmel og hav og planter og træer udenfor, der sandsynligvis ikke siger noget om sig selv. Der er de andre mennesker. Der er forholdet imellem alle disse fænomener, som vores fortællerjeg kredser om.

Nu skriver jeg, at der er en bevidsthed, der skriver jeg om sig selv. Måske ville det være mere korrekt at tale om den specifikke del af bevidstheden, der siger jeg om sig selv. Eller at tale om den del af det sansende menneske, der opfatter sig selv bevidst. For ud over alt det ydre, en bil der kører forbi ude på vejen f.eks., må jeget også forholde sig til et kolossalt indre landskab, der bestemt ikke kan kendetegnes ved at være én kæmpe, flad og tætklippet græsplæne. Det ville snarere være sådan noget som at stå i en tæt skov for foden af en foldebjergkæde. Et indre landskab, der kan benytte sig af ord, men oftere udtrykker sig i stemninger, slørede erindringsbilleder og naturligvis i drømme. Drømme om både 
og flasker f.eks. Som om alle de forskellige dele, bevidstheden med tilbehør består af, skubber jeget rundt som en båd (en fladbundet båd med en cirkelrund forsænkning i midten). Som alle andre både, søger også jegbåden en havn, specielt hvis det stormer lidt for meget omkring den. Men en sådan havn findes ikke. Der findes kun en tilnærmelse til den - en velkendt stemning, lyset i gaderne i december, barndommens badebugt osv. Alt sammen noget, der har været, som båden kan lægge sig tæet op af og finde hvile. Det er altid bedre end ingenting.

Det besværlige ved jeget er, at det er afskåret fra at betragte sig selv udefra. Ligemeget hvad det gør, kan det ikke søge sig selv, fordi jeget kun søger șig selv med sig selv. Men man kan forsøge at skabe en kunstig afstand, og en mulighed jeget har, er at søge sig selv gennem skriften. Jeget kan spørge i en tekst: Hvad består jeg af? Og forsøge at svare. Af en sovsekande med et cirkelrundt hul? Af en flaske, der nøjagtigt passer ned i? Af begge dele? Og hvis jeg består af disse ting, er det så deres faste kanter, jeg består af, eller er det af det tomrum, deres kanter blot afgrænser?

Skriften kunne også søge et andet sted. Det kunne være, at jeget bestod af noget helt andet, af et stykke brændende træ, måske, som var i stand til at falde ud gennem to lukkede jerndøre. Det kunne selvfølgelig også være, at det var de to lukkede jerndøre, der var jeget. Men det er trods alt det brændende stykke træ, der falder ud gennem jerndørene og ikke omvendt, så hvis der er liv i jeget endnu, er det træet, der er det bedste bud på, hvor fortællerens jeg befinder sig. Men det er ikke det jeg, novellens fortæller søger, det brændende stykke træ bliver omhyggeligt og metodisk skovlet ind til ilden igen, hvorefter det fortællende jeg bliver grebet af en stærk uvirkelighedsfornemmelse. Er jeg noget, en anden har drømt, spørger det? Er jeg drømt af et stykke træ i en brændende kamin? Er jeg drømt af ilden? Eller er jeg, som ilden, væk i samme øjeblik, jeg brænder?

Der er selvfølgelig også den mulighed, at jeget slet ikke er i stand til at finde et jeg, trods teksten, trods skriften, fordi der ikke er noget jeg at finde. Måske ville det endda være en befrielse, helt at opgive sin søgen, være en tom gynge, der blæser i vinden og bare gå i ét med havet. Men allerede mens jeget sukker af lettelse 
over at opgive sig selv, melder den næste tanke sig. Er havet et jeg og den landfaste jord kroppen? Eller er jeget måske himlens grå farve, der som jeget på en gang skifter umærkeligt og er helt distinkt. Den samme grå farve, og alligevel en helt anden grå farve. Man kan se forskellen i den grå farve tydeligt på baggrund af et helt hvidt flag. Den grå farves næsten menneskelige skiften ansigt.

Hvis jeget er havet. Hvis jeget er den grå farve. Hvad er så jegets kendetegn? Det er vel at være en bevægelse, enten som rytmiske bølger mod en strand, eller som den grå farves gliden frem og tilbage over farveskalaen, og det er snarere selve den bevægelse, der er kendetegnet, end det er indholdet. Havets indhold er hav. Farvens indhold er farve. Havet er en konstans, siges der i novellen. Det er jeget også, inden for sin egen levetid. Det er smertefuldt og befriende. Det er det samme jeg fra start til slut, det samme tonehovede, der kører henover livet, det ser de samme ting dag efter dag, og når det vender tilbage til sit barndomshjem, kan det ikke undgå at genkende udsigten, den måde lyset er på lige der, den stemning, der følger med. Der er ingen egentlig ændring, kun forskydninger, jegets indhold er selv jeget. Det er ikke lige det arbejde, man fik i sidste uge, det handler om, det menneske man giftede sig med, eller den lejlighed, man indretter. Det er krusninger på overfladen af det samme hav, der bærer sig selv med rundt i en krop, der i en umærkelig bevægelse ændrer sig.

Denne konstans i jeget har det med at føle sig oprørt, nærmest harmdirrende over kroppens ændringer. Det er ikke til at holde ud at se, hvor midaldrende andre midaldrende mennesker ser ud. Man nægter at kendes ved den del af sin eksistens, som tiden er herre over. Midaldrende mennesker, der klæder sig i babyfarver. De kan umuligt være som jeg er, indeni. Man må undgå dem, undgå deres blikke, hvori man kunne frygte at se en genkendelse af sig selv, af sin krops alder. Tænk hvis de så en midaldrende mand i sit sommerhus. For det gælder ikke, det med kroppen. Det gælder aldrig. Næsten ingen mennesker forstår, hvor gamle de er. For der er jo barndommen, som lige har været her, med sine dugvåde strømper gennem skoene, og et helt spe- 
cielt lys på himlen, som var uendeligt, og tiden var en stor rund kugle, som dem der hang på juletræet, uden hverken begyndelse eller slutning.

Fornemmelsen af tiden som en kugle holder oftest op, man ser de andre dø, man ser dem fødes. Men man kan søge efter den fornemmelse, længes efter den, efter fornemmelsen af ikke at blive ført noget sted hen, men bare at være, i en slags tomhed, der som havet, farven grå og jeget, er en konstans, hvis indhold er den selv.

"Time out". Hvis nu man tog en anden synsvinkel og sagde, at jeget simpelthen er tiden, så ville det være jeget, der var out i novellen: For som med havet og farven grå, har jeget også fælles træk med tiden. De er lige uhåndgribelige. Lige lidt tilforladelige. I lige høj grad et tredimensionalt skema, hvor én pil viser den lige vej frem uden slinger i valsen, og en anden pil viser et helt andet sted hen, til en dybde, og de to pile er indbyrdes afhængige. Den dybde, der udspiller sit liv omkring jeget, har stor indflydelse på hvordan jeget lever det daglige, lineære liv. Og det liv, der skrider frem, påvirker dybden, fylder den med minder, billeder, smerte, faldende orgasmer. Hvis man vil nærme sig dybden, kan man forsøge i en tid at stille sig udenfor det almindelige, fremadskridende liv. Man kan træde ud af sin vante rolle og nærme sig noget andet. Men hvis rollen er tætsluttende, kan det være svært at nå noget andet. Det er trist, hvis man kun føler, man er noget, hvis man spiller en rolle, og trist hvis man sammen med andre mennesker ikke ser sig i stand til andet end at spille en rolle. Dybden har større klangbund, hvis den får lov til at følge med hele tiden, og ikke kun viser sig som et sjældent afsat punkt $i$ det tredimensionale skema.

Et andet lighedspunkt mellem jeget og tiden er, at de hele tiden gemmer sig. De er der hele tiden, de er ikke væk på noget tidspunkt, men alligevel er de her slet ikke, de kan ikke gribes. Vi er midt $i$ tiden, uden mulighed for at slippe væk fra den, og vi er midt i vores eget jeg, uden mulighed for at slippe væk fra det. Man kan forsøge at slippe væk fra sit eget jeg, det er klart. Men sandsynligvis vil ens små idiosynkrasier stå i vejen (jeg kan ikke se havet, hvis der går et andet menneske foran). Eller ens barn- 
domserindringer, dufte, der bringer én lige lukt tilbage til dengang, hvor duften bare var noget, der var i forbifarten på vej ind fra rundbold.

Hvis man gerne vil slippe væk og ud af det jeg, der på en eller anden måde insisterer på at tænke én, kan man sige, at der ikke er nogen forskel på noget som helst. For hvis der ikke er nogen forskel på det omkringliggende landskab og mit eget jeg, så har jeg muligheden for, vupti, at slippe ud af mig selv. For så kunne jeg jo lige så godt være det der stykke dugvåde brænde, der ikke er båret ind fra haven endnu, eller jeg kunne være lidt bølgeskum, for de to ting er jo det samme.

Ville der så ikke være den længe ønskede konstans, enhed og smertefrihed i foretagendet? Så skidt med, at det hele er lidt gråt i gråt, jeget ville få mulighed for at hvile sig. Og hvem kan ikke trænge til at hvile sig?

Teksten spørger. Jeget spørger. Man søger, men på en eller anden måde er tingene hele tiden de samme, med små forskydninger i farven, i stemningen. Man skal snart hjem fra sommerhuset igen. Men hverken havet, den grå farve eller det søgende jeg forsvinder. Verden er som den er. 
